\title{
Ssciendo
}

Ethics \& Bioethics (in Central Europe), 2020, 10 (1-2), 78-95

DOI:10.2478/ebce-2020-0002

\section{Unethical practices in the Slovak business environment: Entrepreneurs vs. the State?}

\author{
Anna Remišová ${ }^{1}$ \& Anna Lašáková2
}

\begin{abstract}
This paper critically analyses one of the unexpected results of qualitative research aimed at detecting the presence of unethical business practices in Slovakia. The authors seek to find out why entrepreneurs participating in this research do not take responsibility for the development of business ethics and why, in their primary reflections on unethical practices in the Slovak business environment, have they shifted it almost completely to the State level (1), and whether their attitude is morally justified (2). The main theoretical foundation in the following analysis is the theory of development of business ethics on three levels (micro, mezzo and macro), also known as the "subjectmatter of business ethics" approach. The paper discusses attitudes of the research sample, including Slovak entrepreneurs and company representatives, towards the State, and the consecutive critical reflection of their opinions shows that businesspersons tend to give up on their own proactive approach to the development of business ethics and position themselves in the role of an "expectant" instead of a "creator" of ethical standards in society. Furthermore, the paper points out that businesses lack ethical self-reflection in relation to corruption, more precisely, they lack reflection of their place in the corrupt relationship with the State. Given these findings, the paper concludes that an essential basis for the long-term development of business ethics in our country is the establishment of partnerships between the State and business entities, while recognizing the place of nongovernmental democratic institutions.
\end{abstract}

Keywords: subject-matter of business ethics, micro level, mezzo level, macro level, business ethics, unethical practices, entrepreneurs, state, Slovakia, CEE.

\section{Introduction}

This paper deals with an unplanned and unexpected finding obtained during the currently conducted research project on the recent state of business ethics in Slovakia. More specifically, one of the main research questions that was posed to research participants (i.e., Slovak entrepreneurs, business owners and higher management representatives) during the qualitative stream in the respective research project was "What unethical practices do you encounter in the Slovak business environment?" Contrary to common expectations, the respondents did not begin by pointing out the unethical practices carried out by businesses, but they started by naming those practices of the State they perceived as unethical. In other words, in reflecting on the state of ethics in the Slovak business environment, entrepreneurs spontaneously primarily focused on sharp, in some cases even antagonistic, criticism of the State.

Resentment in business-State relations is not a new phenomenon in Slovakia. Research evidence implies that there are problems in the relationship between entrepreneurs and the State, connected with the fact that business is not nested in society and cooperates with other societal institutions (Remišová et al., 2019). Research shows that small firms in Slovakia especially see the business environment as a battlefield, in which they are fighting constantly with the State administration and against harsh legal obligations (Remišová \& Lašáková, 2018). Prior foreign studies on small and medium-sized enterprises (SMEs) also show that smaller companies must fight for survival in global competition (Enderle, 2004), they find it extremely difficult to translate socially responsible behaviors into their practice (Ciliberti et al., 2008), they often struggle with the pace of changes in the business environment that might lead to reduced ethical considerations in business decisions (Arend, 2013), and would definitely need more know-how on how to build ethical infrastructures in their companies (Fernández \& Camacho, 2016). The authors note the need to especially reflect small retailer-supplier relationships from an ethical

\footnotetext{
${ }^{1}$ Comenius University, Faculty of Management, Bratislava (Slovakia); anna.remisova@fm.uniba.sk

${ }^{2}$ Comenius University, Faculty of Management, Bratislava (Slovakia)
} 
perspective (Hwang \& Chung, 2018) and some studies point also towards the local embeddedness of SMEs and the related social proximity that influences the quality of the relationships with stakeholders and under certain conditions may facilitate unethical structures (Lähdesmäki et al., 2019).

From a more global point of view, some authors note on a "return of the State" in business, with intensified State-led interventions causing imbalance between the public and private domains (Sallai \& Schnyder, 2020). However, for Slovak businessmen, it seems that the State has never actually left the business arena, since insensitive interventions in the form of frequent changes in legislation, senseless regulations, non-transparent and chaotic information provided to the business community and occurrence of exceptions from rules, all pertain to the Slovak business environment. As intensified regulation discourages the formation of trust (Aghion et al., 2010), it seems the more the State intervenes in business, the less entrepreneurs believe in the legitimacy of State interferences. On the other hand, another factor that undermines trust in society-business relations is the divergence between what companies say and what they do in practice. This phenomenon is commonly known in the available literature as the problem of corporate social responsibility (CSR) decoupling, which refers to the gap between CSR disclosure and CSR performance and a discrepancy among CSR policies, implementation of CSR programs, and CSR practices (García-Sánchez et al., 2020; Graafland \& Smid, 2019; Sauerwald \& $\mathrm{Su}$, 2019). In addition, prior studies warn that unsatisfactory relations between business and society might stem from the principally negative attitude of the public towards entrepreneurs who are often stereotypically accused of unethical wealth accumulation at the expense of the legitimate needs and interests of other stakeholders (Haynes et al., 2015; Hofstede, 2009; Petrovskaya et al., 2016).

Capitalizing on a rich array of qualitative data, this paper aims to pinpoint the negative attitude of business entities towards State institutions, but on the other hand, and more importantly, it points to an absence of their own ethical self-reflection. This intriguing finding was one of the main conclusions of the qualitative research strand, carried out within broader comprehensive research on the development of business ethics in the Slovak business environment, which was conducted at the Faculty of Management, Comenius University in Bratislava between 2017 and 2018. In this article, we attempt to locate and adequately interpret the relevant causes, which led entrepreneurs to asymmetrically allocate responsibility for the development of business ethics at the macro and mezzo levels.

\section{Research methodology in brief}

The abovementioned qualitative research strand that serves as the data source for the purposes of this paper, was originally designed as an exploratory study with a broader aim to create a map of unethical practices in the Slovak business environment and best practices ethics management firms in Slovakia use to build an ethical workplace. We planned to use the acquired data as an objective initial database of knowledge for the subsequent quantitative representative research that was aimed at mapping the current state of business ethics development in Slovakia. ${ }^{3}$

The main research informants were company representatives and entrepreneurs, mainly because these people are directly involved in business and might therefore understand best the current problems and challenges of the business environment. The main method utilized in this research was the focus group method (FG). It is a relatively frequently used and wellestablished qualitative method of data acquisition (Cowton \& Downs, 2015), which collects data through a discussion between the participants in a small group under the guidance of a

\footnotetext{
${ }^{3}$ This comprehensive multi-method research project no. APVV-16-0091 "Development of business ethics in the Slovak business environment" is being conducted at the Faculty of Management, Comenius University in Bratislava between 2017 and 2021.
} 
moderator/facilitator in order to find out the attitudes and opinions of respondents in relation to the research object. The output of the focus group is qualitative information, how people understand certain issues or phenomena, or alternatively what opinions appear between them in relation to the object of investigation. The respondents should be individuals who have something to say on the subject matter. In the selection of respondents, we focused on ensuring that each FG was different in its composition, with the intention of eliminating the potential unilateralism of entrepreneurs' opinions and experiences. This approach was followed in our research in selecting respondents for individual FGs, thus ensuring a relatively wide range of knowledge about unethical practices in our business environment.

In this research, we carried out four FGs. The first (FG1) consisted of representatives of business and employer organizations in Slovakia (BEOs). This FG was supposed to guarantee a broader perspective in the analysis of the business environment and to provide the already generalized experience of hundreds of business units. We assumed that these business associations have an objective reflection of the Slovak business environment, are able to grasp the issues from several points of view and they also know the legislative framework for doing business in our country. The conclusions and attitudes of BEOs regarding the business environment are also recognized by State institutions. BEOs actively enter into discussions on business-related laws. In total, eight respondents from seven BEOs participated in FG1.

The respondents for the second FG2 were selected from a set of business entities that had already actively applied business ethics or corporate social responsibility into their organizational structures and were rewarded for doing so. We have labelled these enterprises as "rewarded enterprises" (REWs). As a guarantor of their ethical activity and responsibility, we have chosen the prestigious Pontis Foundation, which has been dedicated to the promotion of socially responsible companies since 1998 (Nadácia Pontis) and the results of its decisions are widely recognized. The selection of respondents for FG2 aimed at gaining data from companies that are more critical as well as sensitive to unethical practices in business. There were eight respondents from eight companies in this focus group in total.

The selection of respondents for the other two FGs was based on company size. Actually, it is company size that was methodologically important in our research on the application of business ethics. We are of the opinion that it is one of the factors that influence the process and quality of application of business ethics in practice (Remišová, 1997; Remišová, 2011). Differentiation of companies was done according to the recommendations of the European Union $^{4}$ based on the number of employees, apart from the economic indicators of the given company. The classification by size was as follows: micro company with $0-9$ employees, small enterprise with $10-49$ employees, medium-sized enterprise with $50-249$ employees, and large enterprise with $250+$ employees.

The third focus group (FG3) consisted of respondents whose companies belonged to micro, small and medium-sized enterprises (SMEs) category. The social and economic importance of these enterprises is undeniable - they account for $99.99 \%$ of all business units and employ approximately $74 \%$ of the workforce in Slovakia. ${ }^{5}$ We anticipated that these respondents would have first-hand detailed experience with the common ethical issues related to economic and entrepreneurial activity, as they are direct actors in everyday economic life. Six respondents from six SMEs attended FG3.

The mosaic of views on unethical practices was completed by the respondents of the fourth focus group (FG4), which consisted of respondents from large companies (LACs). We assumed that FG4 would mainly be represented by the local branches of foreign multinationals that might not only have the desired "outside perspective", but, above all, these organizations might have

\footnotetext{
${ }^{4}$ Recommendations of the European Commission no. 2003/361/EC, or regulation of the EU no. 651/2014.

${ }^{5}$ The given data are from the year 2017. See the report by SBA: Malé a stredné podnikanie v čislach v roku 2016 [Small and medium-sized entrepreneurship in numbers in the year 2016]. Bratislava: Slovak Business Agency.
} 
rigorous leadership ethics, compliance programs and codes of conduct (Bohinská, 2018a; Bohinská, 2018b; Lačný et al., 2018; Remišová et al., 2016). Therefore, we assumed these companies could offer new and valuable insights into the way Slovak business is flawed by various unethical issues. This FG consisted of seven respondents from six large companies.

The number of respondents in each FG was proven adequate as, according to Cowton and Downs (2015), the general practice is to use smaller groups in order to secure for the participants enough space for their own contribution to the topics. In their summative analysis of focus groups used in business ethics research that appeared in reputable journals, the authors show that the number of respondents per FG usually varies from twenty to four (Cowton \& Downs, 2015). Likewise, other authors also note that the number of respondents is not as critical as the appropriately addressed methodological rigour in conducting FGs. For instance, Breen (2006) suggested ten to twelve respondents, Painter-Morland and Deslandes (2017) utilized three FGs, Schons et al. (2017) conducted three FGs with four to six participants each, Fernández and Camacho (2016) included 28 respondents in their qualitative research, Carter and Baghurst (2014) conducted their research with two focus groups with eleven participants altogether, and Clarke et al. (2013) worked with 22 respondents in interviews and two mini FGs (each consisting of three people). Thus, the use of FGs is proven to be a standard methods of data acquisition in business ethics research, where not the quantity of respondents, but the quality of the methodological background is essential. As for the respondents in this study, they had diverse experiences from various spheres of business, with direct involvement in doing business on a professional basis. Overall, we gathered a rich dataset encompassing the opinions of 29 respondents, who were knowledgeable experts in their areas as business owners, business executives, top managers, ethics and compliance managers, human resources managers, spokespersons and chief executive secretaries in their respective organizations.

The FGs were carried out from November 2017 to April 2018. They all had the same scenario. The discussion moderator (one of the research team members) introduced the topics to the respondents, informed them about the main objectives of the project and what the purpose of the FGs was in the overall research design. Respondents were informed that the research focused on ethical issues of the business environment at the mezzo level; that is at the organization/company level. The main inquiry tied to the purposes of this paper aimed at answering the question "What unethical practices do you encounter in the Slovak business environment?"

The course of the meetings was open, respondents did not choose from default answers, but formulated their experience in their own words. Since the aim of the FGs was not to ascertain whether the respondents' claims were true or false, the moderator's role was to conduct a discussion with the intention not to derail from the topic and to ensure that all respondents had an equal opportunity to express their views. The FGs took three hours on average. During the meeting, three research team members noted down what was discussed. Their transcripts were then compared, and the missing verified data were added into the final transcript of the individual FG meetings. After finalizing the transcripts, the personal data on the respondents were anonymized and the materials were thoroughly analysed. Each of the respondents was coded as R1, R2, etc. In this paper, we code respondents based on the FG in which they took part; for instance, the individuals who took part in the FG3 are coded as FG3R1, FG3R2, etc.

After the last FG4, the research team produced a summative report on the state of business ethics in the Slovak environment. In the process of detailed scientific processing of the content of FGs, we applied scientific methods of analysis, synthesis, abstraction, induction, deduction, generalization, interpretation and hermeneutics. At this stage, one of the most difficult theoretical problems was to compare the answers of respondents across the FGs, because the research participants expressed their opinions freely in a language natural to them and thus sometimes the same phenomena were labelled using different expressions. In connection to 
that, in order to locate the core themes and raise the clarity of findings, we coded the transcribed material in VOSviewer for constructing and visualizing the network of co-occurring terms that appeared across the four FGs. The thematic map, which emerged from textual data, and related discussion to the research findings are presented in the next section.

\section{Results and discussion}

A comprehensive critical analysis of the responses in the FGs has shown that, in addition to the expected results - to gain an overview of unethical practices in the Slovak business environment and of the best practices in ethics management according to our respondents, there is another issue that we did not originally plan to address. In other words, a new task of analysing "unplanned scientific externalities" emerged during this research. The stated issue is as follows: Despite the diversity of FGs, as well as their varied representation in terms of economic areas or respondents' professional positions, in nearly all FGs, and especially in FG3 with SMEs, the respondents began to reflect on unethical practices in the business environment with uncompromising and massive criticism of the State practices they experienced while conducting business as unethical and negatively affecting the development of business ethics in Slovakia. In FG3, the discussion even started with the sentence: "We welcome your activity, because frankly speaking, it is about time that something happened at State level" (FG3R3). The respondents did not turn their attention to the unethical practices carried out by the business entities themselves until the discussion facilitator cautioned that the actual purpose of the meeting was to reveal how the business entities, by their unethical practices, harm other businesses as well as the overall economic system in the country.

Figure 1 presents the thematic variety in respondents' authentic reactions to the abovementioned research question.

Figure 1: Thematic map of respondents' perceptions of the State in the four focus groups

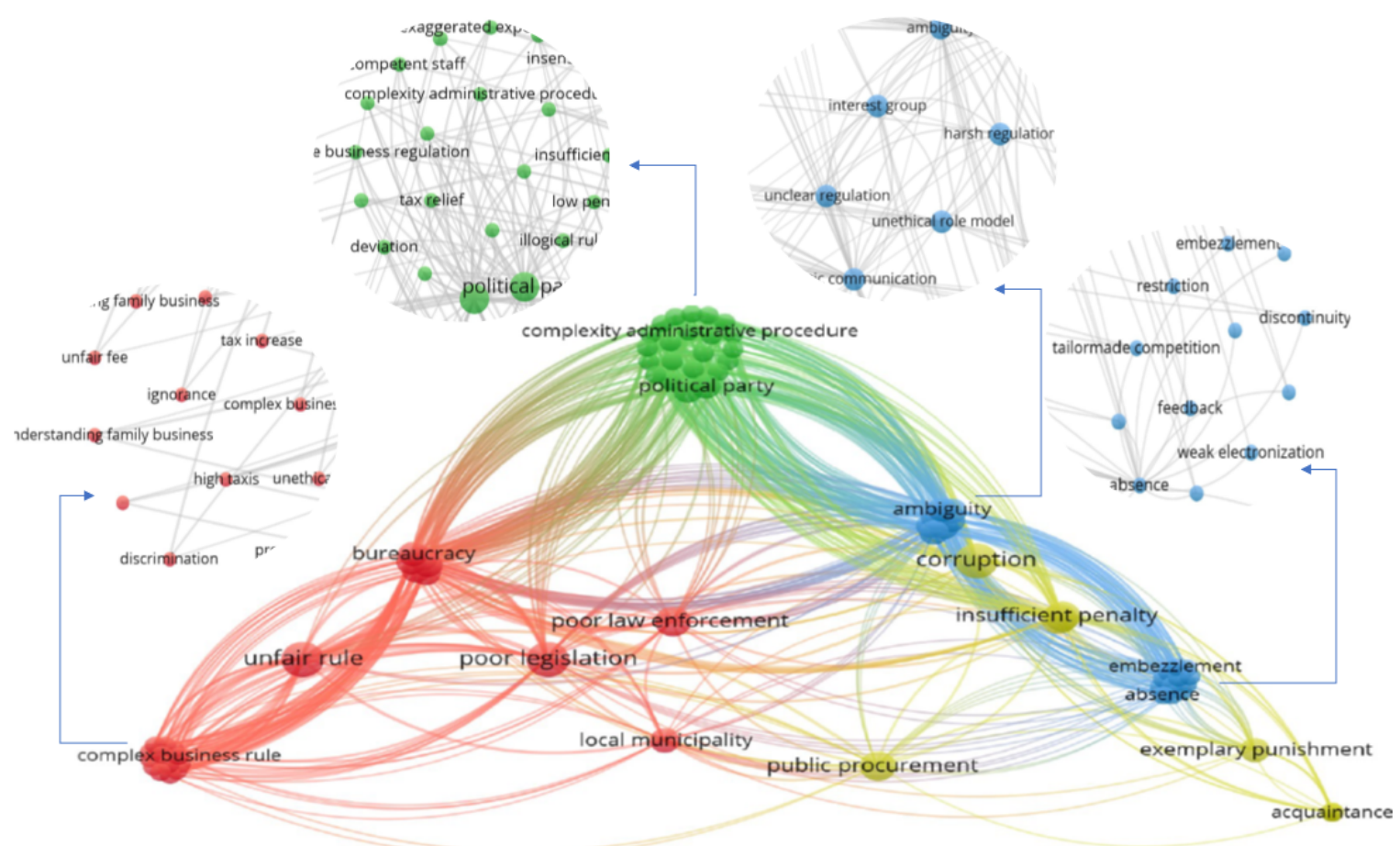

Looking at Figure 1, FG3 with SMEs (red colour cluster) brought up topics like the complexity of the business environment, high levels of bureaucracy, unfair and harsh business regulations with poor law enforcement and overall inadequate legislation. FG1 with BEOs (green colour 
cluster) shared some of these topics with the other FGs and added some issues like the intrusion of politics into business, financing political parties using private business, running the party as a business entity. Overall, respondents from FG1 perceived the State as a bad role-model for business. The issues brought up in FG2 with REWs (blue colour cluster) were somewhat less intense and focused mainly on topics commonly found in the other FGs (e.g., poor State communication State with businesses, ambiguity in the business environment, embezzlement of money in public procurement, absence of standards and clear regulations). Finally, FG4 with representatives of large companies (LACs, yellow colour cluster) shared the perception of corruption, problematic public procurement, insufficient penalties for unethical business conduct, lack of exemplary punishments, nepotism and doing business with close acquaintances like friends or family with the other FGs.

As mentioned above, the issue we are addressing in this paper was not one of our core research questions. However, its moral intensity "forced us" to seek answers to it. Why did business entities spontaneously concentrate on the unethical practices of the State, and not on the unethical practices of business entities themselves? Why did business entities transfer responsibility for the development of ethics in the Slovak business environment primarily to the State? Does the Slovak business environment lack critical self-reflection?

Obviously, the approaches to find answers to these questions are diverse, and we find it particularly interesting to consider a new institutional theory where the roots of this phenomenon are associated with the influence of informal and formal institutions on contemporary economic life (North, 2005; Van Liedekerke \& Dubbink, 2008). In addition, a historical-political view that would take into account the impact of the political and economic transformations that our country experienced in the last century might be instructive in this context (Baláž, 2006; Bohatá, 1997). In our study, we decided to apply the theoretical basis, according to which the development of business ethics takes place simultaneously on three social levels, that is at the micro, mezzo and macro levels. These are also known as the subjectmatter of business ethics - an approach that underpins the understanding of business ethics in the Bratislava School of Business Ethics (Remišová \& Lašáková, 2017). Such an approach seems methodologically legitimate: in our research we have focused on the unethical practices of organizations - on the mezzo level of the development of society, nevertheless, the research informants focused on the unethical activity of the State, that is on a macro-level entity. We consider it meaningful to analyse the attitudes of our respondents on the basis of a theory that strictly defines the roles and responsibilities of the business subjects for the development of business ethics in a given country. ${ }^{6}$

What is the essence of the theory of the development of business ethics at three levels of society? The acceptance of the multilevel analysis of business ethics is based on the fundamental works of Kenneth E. Goodpaster (Goodpaster, 1992) and Georges Enderle (Enderle, 1993; Enderle, 1996; Enderle, 1997). It is not quite possible to speak about ethics, values, interests or responsibilities in connection with economic activity at a flat rate, because these values, interests and responsibilities always have their specific bearer - either a particular person, an organization, or an entire social system. Goodpaster titled this analysis "the subjectmatter of business ethics" (Goodpaster, 1992, p. 112). The primary starting point of this differentiation is the identification of the key subject/actor of human activities in the society. At the micro level, the central subject is an individual, at the mezzo level it is an organization, and at the macro level it is the State with its governing and legislative bodies and the related judiciary. The micro level in business ethics represents an individual as a real existing and operating entity in the sphere of the economy, who can act as an employee, client, consumer,

\footnotetext{
${ }^{6}$ The literature gives evidence that besides these three levels, the global level of business ethics might be considered, too. The main actors in business ethics development at this level are organizations that operate worldwide, and their impact is truly global, for instance the UN, WTO, AVAAZ, or Greenpeace.
} 
entrepreneur, shareholder or manager, etc. Entrepreneurial ethics at the micro level is the ethics of each individual and thus does not only apply only to a manager or an entrepreneur.

At the mezzo level, it is the organization that bears the values, conscious decisions, as well as responsibility for its activities. Here, the organizations operate in various forms, for instance as businesses, multinationals, trade unions, professional associations, NGOs, hospitals, schools, etc. In other words, any legal person whose activity is in some way related to economic and commercial activity. However, it is the business actors who remain the key actors of business ethics at this level.

At the macro level, the business ethics is connected to the activities of governmental and legislation authorities and the judiciary, that is with the activity of the State in the unity of its three pillars of power. By its activities, measures and laws, the State creates a politicallegislative framework within which economic, financial, tax and social policies are implemented, and international economic strategies are set. In particular through legislation, the State creates a social space for the pro-ethical or unethical behaviour of organizations and individuals.

An important moment in the three-level theory of business ethics is the understanding of the interconnection of these three levels. All three levels are essential for the development of business ethics. These levels are not isolated from each other but overlap and interact. In terms of long-term development, every level is essential, and everyone counts. If one level fails in the development, its role may temporarily be replaced by another, but cannot be fully compensated. "The idea that there are three distinct but interrelated levels of business ethics in not only an expository convenience. It suggests that each of the three levels presents appropriate subjects or objects of ethics inquiry. This means that there is some degree of freedom or discretion assumed at each level, i.e., that the ethical values found at one level are not merely deterministic functions of the other levels" (Goodpaster, 1992, pp. 112-113).

The division of the micro, mezzo and macro levels in business ethics is of key methodological significance because of three reasons. First, it enables to clearly define who specifically applies business ethics into practice in various spheres of economic life. Second, this approach defines who is the subject of responsibility - moral agents, thus determining who is responsible for the ethical and moral state and development of business ethics in practice, and who is responsible for unethical behavior in economic life. ${ }^{7}$ Third, it is possible to coordinate the development of business ethics among the three pivotal social actors, or to temporarily compensate for the "failure" in activities and the loss of responsibility of a social entity.

We will try to explain the critical attitude of our respondents on the basis of these three dimensions. The first dimension of the theory of the three-level development of business ethics shows that each level represents a different social territory, where the competence to develop business ethics is attributed to a specific social subject. This means that the State has its social

\footnotetext{
${ }^{7} \mathrm{We}$ are aware that there are many definitions and understandings of the phenomenon of responsibility in philosophical and ethical literature. In our business-ethical considerations, we understand the moral responsibility as a three-dimensional social relationship in which an entity (an individual or a collective) voluntarily subscribes to its actions and its consequences and accepts the rewards or sanctions associated with them. Reflection of one's own behaviour and acceptance of responsibility takes place based on the relationship to the respected moral authority. Such a moral authority may be personal conscience, God, a group, but also nature, or future generations. There are three questions to be answered in the definition of responsibility: Who bears the responsibility? What is the subject responsible for? Who or what is the "judge" (evaluator) of his/her actions? Our understanding is based on an understanding of responsibility developed by Ottfried Höffe and Gertrud Nunner-Winkler (Höffe, 1992, Höffe, 2008; Nunner-Winkler, 1993) and see also works by Anna Remišová (Remišová, 1997; Remišová, 2011). In addition, as for the ethical quality of an action, we assume that the motives as well as the consequence of one's actions must pass the test of both the deontological and the teleological ethics. What outcomes are considered to be ethically correct, positive or good within the context of consequentialist ethics see also the works by Vasil Gluchman (Gluchman, 2008; Gluchman, 2017).
} 
territory, in which it manifests itself as a developer of business ethics in the economy. On the other hand, the company also has a pre-defined territory, where it acts as the creator and developer of business ethics. Such a social territory for a business entity is its company as a social organization. In other words, if business ethics is not developed in the company, ethical mechanisms are not applied or an ethical infrastructure is not created, it is not caused by the State's inactivity, but by ignoring business ethics by the management of a particular business entity. In this context, it should be noted that the situation will not change even if people with a high degree of personal ethical integrity and a positive attitude to business ethics work at the micro level in a given company.

The State, in the unity of its three pillars of power, is an active designer of legislative, executive and judicial policies to promote the short- and long-term development of business ethics in society. In the legislative area, laws are adopted that guarantee the development of a market economy on the basis of respect for its main principles - the respect for private property, entrepreneurial freedom, and fair competition. Laws enacted by ruling political parties support the development of business ethics when their content is professionally sound and fair in ethical terms. Executive power is responsible for the governance of the state, and the judiciary guarantees the rule of law, without which the economy in a democratic society cannot develop. Promoting business ethics takes the form of a political-legal framework on the macro level (Ulrich, 1997), ${ }^{8}$ of executive directives and guidelines, and of judicial control and enforcement. State support for business ethics at the macro level can be both direct and indirect. In direct support, the State adopts specific laws that are directly and openly aimed at promoting business ethics. These laws include for instance the law on reporting socially dangerous activity, known as the Whistleblowing Act (Zákon č. 54/2019), or the law on the criminal liability of companies (Zákon č. 91/2016). Promoting ethics is done through the government attitudes and guidelines, but it can also take the form of rewarding ethical firms, or vice versa, creating blacklists for those businesses that break the law. Such forms of support are the Tax Reliability Index, which has been in force since 2018 and is created by the financial administration unit. According to this index, the State rewards business entities that fulfill their tax obligations with 20 different benefits (The state will reward, 2019). Moral sanctions at the national level are, for example, applied in case of entrepreneurs who do not pay levies related to social or health insurance.

Indirect support for the development of business ethics from the State takes place through the impact of laws with a strong ethical charge on the population and entrepreneurs. For example, if taxes are considered unfair by entrepreneurs, this creates a social environment that does not support the development of business ethics, and vice versa. A positive indirect impact on the development of business ethics in our country has been the Civil Service Act, which at first glance is not dedicated to business ethics, but should result in a fundamental uplift in the quality of civil stewardship and improved quality of ethics management in State and public administration organizations, i.e. in ethical cultivation of one of the dominant business partners of the entrepreneurial sector. This law should also contribute to reducing corruption in both the government and the business sphere.

In line with the theory of business ethics development at micro, mezzo and macro levels, we conclude that the criticism expressed by our respondents on the role of the State in the development of business ethics was justified. However, the moral legitimacy of the businessmen's attitude that reflected the logic of "first you, then me", still remains questionable. Businesses put the State first as the creator of the development of business ethics in the country, and assigned themselves a secondary position, as if less important. The perception of themselves as actors in the development of business ethics was absent. Such a view of one's place in the development of business ethics refers to a lack of ethical self-reflection. According

\footnotetext{
${ }^{8}$ Peter Ulrich notes on the so-called Ordnungspolitik.
} 
to such a view, it is possible to justify the absence of one's own ethical activities both in the organizations as well as the lack of systematic support of the State in the development of business ethics throughout the country. For the entrepreneurs, the State is the primary creator of the ethical-economic environment and business entities are just secondary in that. This idea was quite openly expressed in FG3, composed of respondents from SMEs, who believe that the State must first change and then an ethical approach of the business can be expected. In other words, when respondents were asked to talk about unethical practices in the business environment, their responses should include not only reflections on unethical practices by the State, but also self-reflection of their own engagement in developing business ethics, their social responsibility for applying business ethics and for shaping the business environment in our country. Based on the first dimension of the three-level theory of business ethics, we conclude that our respondents had the moral right to criticize the State for failing to develop ethics and to point out practices that they perceive unethical, but it was not morally right to perceive the State as the sole actor responsible for business ethics and to exclude themselves and the other actors from this process, or to condition their ethical actions by waiting for the State first to act and just then enter the process of long-term development of business ethics.

In terms of redistribution of responsibility for the development of business ethics and from the perspective of the second dimension of the theory of three-level development of business ethics, the situation is similar: it is beyond doubt that the State is morally responsible for the state of business ethics in society and must be held accountable for all unethical practices perpetrated by its people in charge. Our respondents' criticism of State representatives is morally justified. However, entrepreneurial subjects, including employers' and professional organizations that defend their interests, as well as individual citizens, are also responsible for developing business ethics. It is therefore essential that entrepreneurs take their own responsibility for the state of business ethics in Slovakia and, from a moral point of view, they will actively cope with the unethical practices they are committing or that are happening with their silent acceptance.

What unethical practices in relation to business ethics have been pointed out by our respondents? The unethical practices could be arranged in three main groups: the first is a summary of unethical practices in the field of legislation, in particular unprofessional legislation, unfair legislation and low law enforcement (1); the second group includes corruption with particular emphasis on abuse of public procurement $(2)^{9}$, and the third group is linked to the absence of disciplinary actions applied by the State on those businesses that behave unethically and illegally, but also the absence of rewards for businesses for their ethical conduct (3).

As we have already mentioned, our goal is not to prove whether our respondents' statements are true, but as long as these practices and attitudes of the State pose a problem for businesses, the State should critically reflect on its activities in the field of business ethics. The results of a long-term international survey of the business environment in the Global Entrepreneurship Monitor (GEM) project show that the Slovak business environment is characterized as one in which "other chronic shortcomings persist - administrative and bureaucratic burdens, high tax and levy burdens, complicated, changing and unpredictable business legislation, problematic law enforcement, clientelism and corruption” (Pilková et al., 2019, p. 17).

\footnotetext{
9 "Public procurement involves the rules and procedures that award contracts, concessions and design contests" acc. to the Zákon č. 343/2015 Z.z o verejnom obstarávaní a o zmene a doplnení niektorých zákonov [Act no. $343 / 2015$ Coll. on public procurement and on amendments to certain acts ], which came into force on 3 December 2015. [online] [Retrieved August 08, 2019] Available at https://www.slov-lex.sk/pravnepredpisy/SK/ZZ/2015/343/20190901
} 
It is therefore clear that the views of our respondents need to be taken seriously, even more because they attribute to these characteristics the "status of unethical practices", which have a negative impact on the development of business ethics in our environment. In line with the theory of the three-level development of business ethics, the idea is that legislation is the exclusive and key sphere of State-led action that creates rules of play for all actors of social life, including the business community. It is also true that only professionally prepared and morally fair legislation supports the long-term development of business ethics in Slovakia. Regulatory directives for entrepreneurship through laws adopted by the executive authorities is clearly perceived negatively by the respondents, as these "are meaningless, illogical, unfair or exaggerated" (FG3R5). It is also clear that if the State fails to ensure respect for the law through a fairly functioning judiciary, collective and individual entities cease to believe in the rule of law and apathy rises, or alternatively, a specific practice is becoming widespread, namely when the injured ones take justice into their own hands. This creates an environment in which the law is not respected. One of the respondents openly admitted that "the established regulatory environment motivates to circumvent the rules" (FG3R6). In this respect, our respondents' critical attitude towards the State in the unity of its three pillars of power is justified and is legitimate. In addition, it can be seen as one of the main reasons why the relationship of businesses towards the State was uncompromising, even antagonistic.

The respondents also criticized the attitude of the State in the application of moral mechanisms of behavior towards entrepreneurs. The State was reproached that it does not use the institutions of rewards and punishments in the business environment at all. Their opinion is clear: "[It is important] to reward ethical and punish unethical behaviour, such an initiative is needed in society" (FG3R2), because "we lack a positive example of someone being affected if they did something unethical" (FG2R1). They believe that disciplining those who violated business ethics would significantly contribute to the development of business ethics, similarly, as the recognition and possible economic advantage to businesses that respect the principles of business ethics would be beneficial for ethical development. In our opinion, this criticism of the State is justified because both the disciplinary actions and the rewards are key regulators in the moral system. It is a process of forming public opinion in which the role of the State is irreplaceable. By publicly recognizing business entities, the State provides citizens with a positive pattern of behaviour, which is a structural element of any moral system. Disciplinary actions have a great impact on citizens' behaviour - to show disagreement with the conduct of a business entity and to openly distance themselves from its conduct is a strong moral lesson. A negative public image is a hidden "nightmare" for any business entity, because if an entrepreneur is serious about business, he must care about the reputation of his company among his customers and in society as a whole. If respondents have pointed out that the State is not active in shaping public opinion favourable to ethical entrepreneurs and vilifying the unethical, it is clear that they have expressed their own experience with the State as an opinion-forming actor and their criticism of the State can be considered relevant.

Corruption was considered the most widespread unethical practice in our business environment. Again, the perception of our respondents corresponds to the results of other researchers, too (for e.g., Zemanovičová \& Vasáková, 2017). According to the Corruption Perception Index (CPI), which is one of the most widespread and recognized international indicators of the state of corruption in individual countries carried out on a yearly basis by one of the NGOs dedicated to the fight against corruption, Transparency International, the level of corruption in Slovakia in 2018 was 50, which ranks Slovakia in $57^{\text {th }}$ place in the CPI ranking (out of 185 surveyed countries) (Corruption perceptions index, 2018). Corruption, in accordance with Transparency International, is understood as misuse of entrusted authority for personal benefit - "Corruption is the abuse of entrusted power for private gain" (What is corruption). Corruption has many forms; it encompasses diverse types of actions like the 
bribery, nepotism, protectionism, or clientelism. In our research, corruption was conceived primarily in connection with the public procurement process: "Regarding unfair practices, I would like to mention ... first, public procurement conditions are set up to fit a particular firm. ... Second, an advantage is created in public procurement through the supply of information to selected firms" (FG4R5).

Traditionally, corruption has been linked with State elites and decision-makers, and this is what our respondents have done, in that, in terms of corruption, they have transferred the moral responsibility to the State. But can macro-level corruption be analysed and tackled? Is it possible to solve corruption without the involvement of business entities in this process? Do the organizations at the mezzo level and the individuals at the micro level bear some degree of moral responsibility for corruption? If corruption and the intrinsically linked abuse of public procurement is the major problem for entrepreneurs, is it not necessary to make a critical ethical self-reflection in terms of developing business ethics? A question is at hand: Am I ready to fight corruption in public procurement? It is widely accepted in the literature that corruption is an economic, political and also an ethical problem. It should be pointed out, however, that corruption is primarily entwined in a socio-economic relationship; at one end of this relationship is someone who has been entrusted by an institution with a certain authority, and on the other end is someone who wants to get a service, no matter whether this is justifiable or illegitimate. In order to secure this claim, whatever other stakeholders might be involved, and the social damage that could be done, one provides the other with some kind of payment (in the form of money, donations, services, promises, help, etc.). In other words, corruption is a business involving two business partners. However, their transaction is socially toxic. As the representatives of legislative, executive and judicial institutions have the competencies, on which entrepreneurs actually rely, the unethical nature of the State en bloc directly affects their business activities and effectiveness. From our perspective, it is morally justified to hold the State accountable for unethical practices associated with corruption. From an ethical point of view, however, it is wrong to assume that corruption is a problem that does not concern the morality of the business environment. Corruption between government and business will continue as long as only one business has an interest in violating fair competition rules. Therefore, as one of our respondents noted, "entrepreneurs need to understand their place in society and take the responsibility" (FG1R5).

In this context, we would like to note three examples that show that the Slovak business environment is not yet sufficiently morally prepared to radically put an end to corruption by its own powers, and thereby distorting "corrupt trade". When the Anti-Corruption Charter, prepared with the support of the then government by Transparency International Slovakia, was signed in 2003, only about 30 business entities signed this commitment. ${ }^{10}$ Here it should be added that it was a document that committed business entities in their business activities to not providing bribes to State representatives. If more businesses were to join this initiative, a strong anti-corruption movement could have been created and the rate of corruption in Slovakia would be significantly lower today. The power of corporate movements is just one, but still a very relevant, factor that can change the landscape of the society. For instance, responsible businesses can be the engine of positive social change (Haugh and Talwar, 2016), can actively participate in peace processes and peacebuilding (Rettberg, 2016), or can redefine roles and responsibilities of various stakeholders and thereby improve the quality of life in wider society (Girschik, 2020). Another example of a similar initiative brought up in 2006 was introduced by the well-established and widely recognized multinational consulting company Accenture, which radically opposed corruption in Slovakia and publicly announced that, for fundamental

\footnotetext{
${ }^{10}$ Prvých tridsat' subjektov podpísalo protikorupčnú chartu [The first thirty subjects signed the Anti-corruption charter].[online] [Retrieved August 31, 2019] Available at https://domov.sme.sk/c/1116762/prvych-30-subjektovpodpisalo-protikorupcnu-chartu.html
} 
reasons, it would no longer trade with the government to avoid any corruption (Čišovský \& Valášek, 2019). It was their own protest against corruption. Even this initiative did not find support among Slovak entrepreneurs. Similar problems occurred with regard to the publicly declared fight against corruption in obtaining government contracts by Skanska in 2009 (Správat' sa nekorupčne, 2012). These initiatives, which could play the role of moral role model in the fight against corruption in the business environment, were left alone. Business entities did not join them.

Thus, it can be concluded that the State bears moral responsibility for the state of corruption in our country, but moral responsibility can also be attributed to the business environment. And until the business environment consciously accepts responsibility for its participation in corrupt activities and finds a way to fight corruption in its own ranks and finds the courage to openly name the offenders, the Slovak business environment will be burdened with this poisonous phenomenon that harms the economy, democracy and the social good.

In our article we only marginally focus on the micro level, i.e., on the application of ethical principles by individuals in everyday economic situations. This level is closely related to the culture of the country, its traditions, rituals, customs. For our respondents, this subject was not primarily associated with unethical practices. However, its functioning is also irreplaceable by other spheres. If we use the example of corruption, it is generally accepted in our culture to thank for services provided and not to take them as something natural to which a citizen of a democratic country is entitled. Therefore, tackling corruption in our country is not possible unless all three levels are involved. The third dimension of the analysis of respondents' replies based on the three-level theory of business ethics development is tied to the understanding of the importance of cooperation between entities operating at the micro, mezzo and macro levels. As we have already mentioned, the development of business ethics is relatively independent at every level, but in general it is not possible to build an integrated business ethics system that guarantees a functional economic order without the cooperation of all entities at the different levels, that is of individuals, businesses and State agencies.

The optimal model of the long-term development of business ethics in this country is the simultaneous active participation of all three levels in the achievement of higher moral standards in the economy. But the reality is different. At some stages of social development, some levels may fail or fall behind. Experience shows that such a failure can be temporarily replaced by an active approach at one of the other levels. The situation that arose in the early economic and political transformation in our country in the 1990s could serve here as an example - the transition from a planned economy to a market presupposed the first major step in privatization of State property; the new system was primarily to create a legislative framework for private ownership and the functioning of a market economy. However, the transfer of State property to private owners took place without any ethical regulation. The then State authorities fundamentally ignored the role of ethics in economic development. For various reasons, they did not declare or support the idea that a market economy presupposes a stable ethical order. Paradoxically, in addition to new business entities that behaved very unethically in relation to the acquired State assets, there were also business entities that were serious about business, and perhaps were the first in our country to understand that their intention to remain on the market in the long term entails the application of ethics into business practice. At this stage, the business environment partially counterbalanced the role of the State in developing business ethics. However, such compensation can only be temporary, as the role of the State in the development of ethics is irreplaceable. On the other hand, it is also possible that the State understands the importance of business ethics, but the business environment prevents its application in business units, or when the business environment is dominated by the instrumental understanding of business ethics, that is if entrepreneurs use business ethics only if it has an immediate positive economic effect for the company. The fact that some of our 
research respondents are aware of their low involvement in the development of business ethics can be documented by one respondent's statement: "Developments in legislation force companies to address ethical issues, but companies are not interested in the spheres [of business activities] that are not legally treated" (FG1R1).

As mentioned above, our respondents attributed a key position in the discussion about unethical practices to the actions that link with the activity of the State in the unity of its three main pillars of power. They also transferred the moral responsibility for unethical practices in business and their consequences to the State. It was only after the moderator intruded on the discussion and refocused the participants' attention that they revealed unethical practices, of which the actors, and thus the bearers of responsibility, were the business entities at the mezzo level. We have not noticed in the attitudes and opinions of business entities that they perceive the State and themselves as partners in the development of business ethics, which could have a future negative impact on the long-term development of business ethics in practice.

It is the separation, or in our opinion, the lack of cooperation between the State and the business entities, which causes negative or hostile attitude of business entities towards the State. Research shows that solutions to the current societal challenges - economic, social, environmental, but also cultural - are not possible without partnership between the State, businesses and non-governmental democratic institutions (Remišová \& Lašáková, 2018; Remišová et al., 2019). In other words, neither the State, business entities nor individuals can create mechanisms for the long-term development of business ethics and introduce them into practice alone. And if so, only for a certain time. The future of business ethics in our country in practice lies in the cooperation and partnership of those who are responsible for its development. ${ }^{11}$

In our study, we focused on analyzing attitudes and relationships between subjects at the mezzo and macro levels. Intentionally, we have not addressed the micro level, but this does not mean that we do not attach importance to this level in the development of business ethics. The level of human moral development, as a specific human product and an outcome of cultural evolution (Gluchman, 2005), needs to be considered with utmost importance. The development of business ethics should be ensured in parallel at all three levels, the bodies responsible for the development of business ethics must communicate with each other, lead a discourse and seek joint solutions. The cooperation to achieve social good is the foundation of a civil society. It is possible that some of the levels may not fulfill their responsibilities for some time or may not have enough moral powers to accept moral responsibility, but this should not be a reason for antagonism between the three levels.

\section{Conclusions and limitations}

This paper critically analysed the underlying reasons for the apparently negative attitudes of the entrepreneurs and company representatives participating in this research. It concluded that our respondents did not consider their responsibility for the development of business ethics, and in their primary reflections on unethical practices in the Slovak business environment, they shifted the responsibility almost completely to the State level. Given that, the paper argued whether their attitude could be morally justified. The main theoretical framework in the respective analysis was the theory of the development of business ethics at three levels - macro, mezzo and micro - also known as the "subject-matter of business ethics" approach. The main conclusions might be structured according to this theoretical approach as follows:

\footnotetext{
${ }^{11}$ For instance, an initiative of the IT sector was developed, where representatives of business associations have proposed how the State could reduce unethical practices in trading. See also: Navrhli sme zmeny k lepšiemu, na rade je štát [We have proposed changes for the better, now it is the State's turn]. [online] [Retrieved August 31, 2019] Available at https:/www.etrend.sk/trend-archiv/rok-2019/cislo-21/navrhli-sme-zmeny-k-lepsiemu-narade-je-stat.html
} 
1) Based on the first "macro" level in the three-level theory of business ethics development, it is legitimate for a business entity to perceive the State as an actor in the development of business ethics and to demand an active professional approach to the long-term development of business ethics. It is not morally justified, however, to give up its own proactive approach to the development of business ethics and to take on the role of an "expectant" instead of the role of a "creator".

2) Based on the second "mezzo" level in the three-level theory of business ethics development, it is legitimate to attribute moral responsibility to the State for its unethical practices. As it turned out, our respondents' views on unethical practices of the State correlate with other research studies, and therefore a critical attitude towards the State is justified in all the three areas of unethical practices. However, it is not morally justified to not accept one's own moral responsibility for the state of corruption in our country. On this issue, there is no ethical self-reflection of business entities in relation to corruption, more precisely the loss of reflection of one's place in the corrupt relationship with the State.

3) Based on the third "micro" level in the three-level theory of business ethics development and the underlying idea of the essential cooperation between these three levels, we conclude that the long-term development of business ethics is impossible without a systematic and purposeful approach of the individual subjects to the responsibility for their activities in the broader business arena, whilst an essential basis for the long-term development of business ethics in our country is the establishment of partnerships between the State and business entities, while recognizing the place of NGOs representing the citizens.

We are aware of the limits of this study. The conclusions are generalized based on a limited sample of business representatives, and, in addition, our results encompass perceptions of entities located at one level only, namely the mezzo level of business ethics development. Nevertheless, our sample included respondents representing diverse areas of business, having different experiences of applying business ethics in companies, with varied experience from professional, employer and business organizations, as well as experiences from various large enterprises. As it was mentioned above, we originally had the intention "only" to monitor unethical practices in the Slovak business environment. However, the findings from the qualitative research strand seemed so serious for our research and for business practice as well, that we considered it our scientific duty to deal with them. By the means of this paper we would like to open up the issues regarding the relationship between the State and business entities in the development of business ethics, as we believe this topic needs to be addressed further both in theory and practice.

\section{Acknowledgement}

This work was supported by the Slovak Research and Development Agency under the contract No. APVV-16-0091.

\section{References}

AGHION, P., ALGAN, Y., CAHUC, P. \& SHLEIFER, A. (2010): Regulation and distrust. In: Quarterly Journal of Economics, 125(3), pp. 1015-1049.

AREND, R. J. (2013): Ethics-focused dynamic capabilities: A small business perspective. In: Journal of Business Ethics, 41(1), pp. 1-24.

BALÁŽ, V. (2006): Politická ekonómia slovenského kapitalizmu: Inštitucionálna perspektíva [Political economy of the Slovak capitalism: An institutional perspective]. In: Politická ekonomie,54(5), pp. 610-631. 
BOHATÁ, M. (1997): Business ethics in Central and Eastern Europe with special focus on the Czech Republic. In: Journal of Business Ethics, 16(14), pp. 1571-1577.

BOHINSKÁ, A. (2018a): Human resource manager's responsibility in creating a culture of legal compliance and ethics in an organization. In: Journal of Human Resource Management, 21(2), pp. 8-15.

BOHINSKÁ, A. (2018b): Role of a compliance program in an organization. In: V. Bartošová \& J. Belas (eds.): Globalization and its socio-economic consequences. Žilina: Žilinská univerzita v Žiline, pp. 476-483.

BREEN, R. L. (2006): A practical guide to focus-group research. In: Journal of Geography in Higher Education, 30(3), pp. 463-475.

CARTER, D. \& BAGHURST, T. (2014): The influence of servant leadership on restaurant employee engagement. In: Journal of Business Ethics, 124(3), 453-464.

CILIBERTI, F., PONTRANDOLFO, P. \& SCOZZI, B. (2008): Investing corporate social responsibility in supply chains: a SME perspective. In: Journal of Cleaner Production, 16(15), pp. $1579-1588$.

CLARKE, C., HARCOURT, M. \& FLYNN, M. (2013): Clinical governance, performance appraisal and interactional and procedural fairness at a New Zealand public hospital. In: Journal of Business Ethics, 117(3), pp. 667-678.

COMMISSION RECOMMENDATION OF 6 MAY 2003 CONCERNING THE DEFINITION OF MICRO, SMALL, MEDIUM-SIZED ENTERPRISES (2003/361/EC). [online] [Retrieved August 31, 2019] Available at: https://eurlex.europa.eu/LexUriServ/LexUriServ. do?uri=OJ:L:2003:124:0036:0041:EN:PDF.

COMMISSION REGULATION OF 17 JUNE 2014 (651/2014). [online] [Retrieved August 31, 2019] Available at: https://op.europa.eu/en/publication-detail/-/publication/1291bb4c-fcfe11e3-831f-01aa75ed71a1/language-en.

CORRUPTION PERCEPTIONS INDEX (2018): [online] [Retrieved August 08, 2019] Available at https://www.transparency.org/cpi2018\#results.

COWTON, C. J. \& DOWNS, Y. (2015): Use of focus groups in business ethics research: Potential, problems and paths to progress. In: Business Ethics, 24(S1), pp. S54-S66.

ČIŠOVSKÝ, K. \& VALÁŠEK, M. (2006): Peter Škodný: IT je špinavý biznis [Peter Škodný: IT is a filthy business]. [online] [Retrieved August 31, 2019] Available at: https://www.trend.sk/technologie/peter-skodny-it-je-spinavy-biznis.

ENDERLE, G. (1993): Handlungsorientierte Wirtschaftsethik. Grundlagen und Anwendungen. Bern: Haupt.

ENDERLE, G. (1996): Towards business ethics as an academic discipline. In: Business Ethics Quarterly, 6(1), pp. 43-65.

ENDERLE, G. (1997): In search of a common ethical ground: Corporate environmental responsibility from the perspective of Christian environmental stewardship. In: Journal of Business Ethics, 16(2), pp. 173-181.

ENDERLE, G. (2004): Global competition and corporate responsibilities of small and mediumsized enterprises. In: Business Ethics: A European Review, 13(1), pp. 51-63.

FERNÁNDEZ, J. L. \& CAMACHO, J. (2016): Effective elements to establish an ethical infrastructure: An exploratory study of SMEs in the Madrid region. In: Journal of Business Ethics, 138(1), pp. 113-131.

GARCÍA-SÁNCHEZ, I., HUSSAIN, N., KHAN, S. \& MARTÍNEZ-FERRERO, J. (2020): Do markets punish or reward corporate social responsibility decoupling? In: Business and Society, doi:10.1177/0007650319898839

GIRSCHIK, V. (2020): Managing legitimacy in business-driven social change: The role of relational work. In: Journal of Management Studies, 57(4), pp. 775-804. 
GLUCHMAN, V. (2005): Idea humanity v kontexte súčasnej etiky [The idea of humanity in the context of contemporary ethics]. In: Filozofia, 60(7), pp. 512-531.

GLUCHMAN, V. (2008): Etika a reflexie morálky [Ethics and Reflections of Morality]. Prešov: FF PU.

GLUCHMAN, V. (2017): G. E. Moore and theory of moral/right action in ethics of social consequences. In: Ethics \& Bioethics (in Central Europe), 7(1-2), pp. 57-65.

GOODPASTER, K. E. (1992): Business ethics. In: L. Becker \& C. Becker (eds.): Encyclopedia of Ethics. New York: Garland Publishing, pp. 111-115.

GRAAFLAND, J. \& SMID, H. (2019): Decoupling among CSR policies, programs, and impacts: An empirical study. In: Business and Society, 58(2), pp. 231-267.

HAUGH, H. M. \& TALWAR, A. (2016): Linking social entrepreneurship and social change: The mediating role of empowerment. In: Journal of Business Ethics, 133(4), pp. 643-658.

HAYNES, K. T., HITT, M. A. \& CAMPBELL, J. T. (2015): The dark side of leadership: Towards a mid-range theory of hubris and greed in entrepreneurial contexts. In: Journal of Management Studies, 52(4), pp. 479-505.

HÖFFE, O. (1992): Lexikon der Ethik, 4. neubear., Aufl., Munchen: Beck.

HÖFFE, O. (2008): Lexikon der Ethik, 7. neubear., Aufl., Munchen: Beck.

HOFSTEDE, G. (2009): Business goals for a new world order: Beyond growth, greed and quarterly results. In: Asia Pacific Business Review, 15(4), pp. 481-488.

HWANG, J. \& CHUNG, J.-E. (2018): The roles of business ethics in conflict management in small Retailer-Supplier business relationships. In: Journal of Small Business Management, 56(2), pp. 348-368.

LAČNÝ, M., LUKÁČOVÁ, J. \& KOVALČÍKOVÁ, I. (2018): Specifics of introducing a code of ethics into the academic environment. In: Ethics \& Bioethics (in Central Europe), 8(1-2), pp. 91-108.

LÄHDESMÄKI, M., SILTAOJA, M. \& SPENCE, L. J. (2019): Stakeholder salience for small businesses: A social proximity perspective. In: Journal of Business Ethics, 158(2), pp. 373385.

MALÉ A STREDNÉ PODNIKANIE V ČÍSLACH V ROKU 2016 [Small and medium-sized entrepreneurship in numbers in the year 2016]. Bratislava: Slovak Business Agency, 2017.

NADÁCIA PONTIS [Pontis Foundation]. [online] [Retrieved August 31, 2019] Available at: http://www.nadaciapontis.sk/o-via-bone-1.

NAVRHLI SME ZMENY K LEPŠIEMU, NA RADE JE ŠTÁT [We have proposed changes for the better, now it is the State's turn]. [online] [Retrieved August 31, 2019] Available at https://www.etrend.sk/trend-archiv/rok-2019/cislo-21/navrhli-sme-zmeny-k-lepsiemu-narade-je-stat.html.

NORTH, D. (2005): Understanding the process of economic change. Princeton: Princeton University Press.

NUNNER-WINKLER, G. (1993): Verantwortung. In: G. Enderle, K. Homann, M. Honecker, W. Kerber \& H. Steinmann (eds.): Lexikon der Wirtschaftsethik. Freiburg im Breisgau, Basel \& Wien: Herder, pp. 1185-1192.

PAINTER-MORLAND, M. \& DESLANDES, G. (2017): Reconceptualizing CSR in the media industry as relational accountability. In: Journal of Business Ethics, 143(4), pp. 665-679.

PETROVSKAYA, I., ZAVERSKIY, S. \& KISELEVA, E. (2016): Putting assumptions into words: money and work beliefs and legitimacy of entrepreneurship in Russia. In: European Journal of International Management, 10(2), pp. 157-180.

PILKOVÁ, A., HOLIENKA, M., KOVAČIČOVÁ, Z., REHÁK, J. \& MIKUŠ, J. (2019): Podnikanie na Slovensku: aktivita, prostredie a vybrané druhy podnikania [Entrepreneurship in Slovakia: Activity, Environment and Selected Types of Entrepreneurship]. Bratislava: Univerzita Komenského v Bratislave \& Kartprint. 
PRVÝCH TRIDSAŤ SUBJEKTOV PODPÍSALO PROTIKORUPČNÚ CHARTU [The first thirty subjects signed the Anti-corruption charter]. [online] [Retrieved August 31, 2019] Available at: https://domov.sme.sk/c/1116762/prvych-30-subjektov-podpisalo-protikorupcnuchartu.html.

REMIŠOVÁ, A. (1997): Podnikatel'ská etika. Úvod do problematiky [Business Ethics: Introduction]. Bratislava: Ekonóm.

REMIŠOVÁ, A. (2011): Etika a ekonomika [Ethics and Economics]. Bratislava: Kalligram. REMIŠOVÁ, A. \& LAŠÁKOVÁ, A. (2017): Theoretical foundations of the Bratislava school of business ethics. In: Ethics \& Bioethics (in Central Europe), 7(3-4), pp. 177-186. REMIŠOVÁ, A. \& LAŠÁKOVÁ, A. (2018): On NGOs' role in the development of business ethics in Slovakia. In: Athens journal of business and economics. 4(4), pp. 389-404. [online] [Retrieved August 31, 2019] Available at: https://www.athensjournals.gr/business/2018-4-4-3Remisova.pdf

REMIŠOVÁ, A., LAŠÁKOVÁ, A. \& BOHINSKÁ, A. (2019): Reasons of unethical business practice in Slovakia: The perspective of non-governmental organizations' representatives. In: Acta Universitatis Agriculturae et Silviculturae Mendeliane Brunensi, 67(2), pp. 565-581.

REMIŠOVÁ, A., LAŠÁKOVÁ, A., RUDY, J, SULÍKOVÁ, R., KIRCHMAYER, Z. \& FRATRIČOVÁ, J. (2016): Ethical leadership in the Slovak business environment. Praha: Wolters Kluwer.

RETTBERG, A. (2016): Need, creed, and greed: Understanding why business leaders focus on issues of peace. In: Business Horizons, 59(5), pp. 481-492.

SALLAI, D. \& SCHNYDER, G. (2020): What is "Authoritarian" about authoritarian capitalism? The dual erosion of the Private-Public divide in state-dominated business systems. In: Business and Society, doi:10.1177/0007650319898475 (forthcoming).

SAUERWALD, S. \& SU, W. (2019): CEO overconfidence and CSR decoupling. In: Corporate Governance: An International Review, 27(4), pp. 283-300.

SCHONS, L. M., CADOGAN, J. \& TSAKONA, R. (2017): Should charity begin at home? An empirical investigation of consumers' responses to companies' varying geographic allocations of donation budgets. In: Journal of Business Ethics, 144(3), pp. 559-576.

SPRÁVAŤ SA NEKORUPČNE NIE JE JADROVÁ FYZIKA [TO BEHAVE UNCORRUPTED IS NOT NUCLEAR PHYSICS]. (2012) [online] [Retrieved August 31, 2019] Available at https://euractiv.sk/section/csr-spolocenska-zodpovednost/news/spravat-sanekorupcne-nie-je-jadrova-fyzika-019242/.

ŠTÁT ODMENÍ FIRMY, ČO SI RIADNE PLNIA DAŇOVÉ POVINNOSTI [The State will reward companies for proper tax compliance]. [online] [Retrieved August 31, 2019] Available at https://finweb.hnonline.sk/ekonomika/1853853-stat-odmeni-firmy-co-riadne-platia-dane.

ULRICH, P. (1997): Integrative Wirtschaftsethik. Grundlagen einer lebensdienlichen Ökonomie. Bern, Stuttgart \& Wien: Haupt.

VAN LIEDEKERKE, L. \& DUBBINK, W. (2008): Twenty years of European business ethics - past developments and future concerns. In: Journal of Business Ethics, 82(2), pp. 273-280.

WHAT IS CORRUPTION: [online] [Retrieved August 08, 2019] Available at https://www.transparency.org/what-is-corruption

ZEMANOVIČOVÁ, D. \& VASAKOVÁ, L. (2017): Corruption as a global problem. In: T. Kliestik (ed.): 17th International Scientific Conference: Proceedings (Part VI.). Globalization and Its Socio-economic Consequences. Žilina: University of Žilina, pp. 3069-3075.

ZÁKON Č. 54/2019 Z. Z. O OCHRANE OZNAMOVATEL'OV PROTISPOLOČENSKEJ ČINNOSTI A O ZMENE A DOPLNENÍ NIEKTORÝCH ZÁKONOV [Act no. 54/2019 Coll. on protection of whistleblowers of anti-social activity and on amendments to certain acts] [online] [Retrieved August 08, 2019] Available at https://www.slov-lex.sk/pravnepredpisy/SK/ZZ/2019/54/20190301. 
ZÁKON Č. 91/2016 Z. Z. O TRESTNEJ ZODPOVEDNOSTI PRÁVNICKÝCH OSÔB A O ZMENE A DOPLNENÍ NIEKTORÝCH ZÁKONOV [Act no. 91/2016 Coll. on the criminal liability of legal entities and on amendments to certain Acts] [online] [Retrieved August 08, 2019] Available at https://www.slov-lex.sk/pravnepredpisy/SK/ZZ/2016/91/20190801.

ZÁKON Č. 343/2015 Z. Z. O VEREJNOM OBSTARÁVANÍ A O ZMENE A DOPLNENÍ NIEKTORÝCH ZÁKONOV [Act no. 343/2015 Coll. on public procurement and on amendments to certain acts]. [online] [Retrieved August 08, 2019] Available at https://www.slov-lex.sk/pravne-predpisy/SK/ZZ/2015/343/20190901. 